\title{
Oral histories as a baseline of landscape restoration - Co-management and watershed knowledge in Jukajoki River
}

\author{
TERO MUSTONEN
}

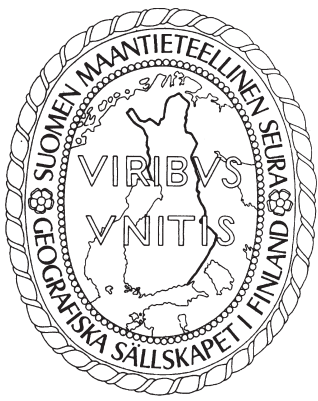

Mustonen, Tero (2013). Oral histories as a baseline of landscape restoration Co-management and watershed knowledge in Jukajoki River. Fennia 191: 2, pp. 76-91. ISSN 1798-5617.

This article explores local oral histories and selected communal written texts and their role in the severely damaged watershed of Jukajoki [and adjacent lake Jukajärvi watershed] located in Kontiolahti and Joensuu municipalities, North Karelia, Finland. All in all 35 narratives were collected between 2010 and 2012. Four narratives have been presented in this paper as an example of the materials. Empirical materials have been analysed by using a framework of both integrated ecosystem management and co-management. Three readings of the river Jukajoki and the adjacent watershed emerged from the materials - Sámi times, SavoKarelian times and times of damages, or the industrial age of the river. Local knowledge, including optic histories, provided information about pre-industrial fisheries, fish ecology and behaviour and bird habitats. Lastly, special oral histories of keepers of the local tradition provided narratives which are consistent with inquiries from other parts of Finland, non-Euclidian readings of time and space and hint at what the Indigenous scholars have proposed as an intimate interconnection between nature and human societies extending beyond notions of social-ecological systems. Empirical oral histories also conceptualize collaborative governance with a formal role of local ecological knowledge as a future management option for the Jukajoki watershed. Watershed restoration and associated baseline information benefits greatly from the oral histories recorded with people who still remember pre-industrial and pre-war ecosystems and their qualities.

Keywords: North Karelia, Jukajoki, co-management, oral history, optic history

Tero Mustonen, The Department of Geographical and Historical Studies, University of Eastern Finland, P. O. Box 111,80101 Joensuu, Finland, E-mail: tero@ snowchange.org

\section{Introduction}

This paper investigates severely damaged watershed of Jukajoki [and adjacent lake Jukajärvi watershed] located in Kontiolahti and Joensuu municipalities, North Karelia, Finland. They are a part of the larger Pielisjoki river watershed. Jukajoki river has received national attention in 2010 and 2011 due to fish deaths caused by discharges of highly acidic waters from the peat production site Linnunsuo owned by the Finnish state-owned energy company VAPO. Both regional state agencies and the company have tried to control and limit the ecosystem damages using science-based methods, knowledge production and monitoring.
They have failed to restore the ecosystem health, nor they have been able to detect the fish deaths that occurred and were identified by the local subsistence fishermen both in 2010 and 2011. The key question explored in this paper is related to the need of an improved management of watersheds in the case of an industrial discharge. More specifically, I explore, what are the possibilities that Finnish local knowledge embedded in oral histories can provide as a source of information both on current events and as a baseline material for restoration actions? Secondly, in light of international scholarship, what are the needs and advantages for a collaborative management of Jukajoki? 


\section{Theoretical framework}

This paper explores models and differing geographical discourses of time and space in the context of watershed restoration and recovery from peat production and other watershed damage, such as ditch drainage (Tanskanen 2000). Theoretically emphasis will be on introducing unorthodox methods (Berkes 1999; Berkes 2012) and knowledge production regimes (see on the need of a grounded approach Ingold 2000, 2004; Martinez 2011; Mustonen 2012a) in the context of addressing damages of peat production. I am arguing that by using integrated ecosystem management, and more specifically processes leading to ecosystembased fisheries management (EBFM) with a strong local knowledge focus possibly more successful conservation and restoration results can be achieved than single-focus site-specific actions in restoration 1 . This builds on the ideas and approaches developed by Berkes (1999; Carlsson \& Berkes 2005; Berkes 2012; Berkes \& Ross 2013).

The village landscape of Selkie is the product of interaction of humans and nature and has been designated as a national landscape by the Government of Finland in 2000. First records of inhabitants are from 1500s, but pre-historic Sámi population utilized the area prior to this time (Selkien kyläyhdistys 2004: $11^{2}$, see on the toponymic Sámi place names of Eastern Finland in Aikio 2007, 2012). Geomorphologically the soil is filled with phyllites extending to the lake Pyhäselkä in the west. In these phyllites there are large concentrations of iron that affects the colour of the minerals. These phyllites indicate that the soil has been affected by lack of oxygen on a former seabed roughly 2000 million years ago. Sulphur and iron play dominant part in the Jukajoki soil phyllites and are the root cause for the high presence of iron in the discharge waters from the peat production sites (Nykänen 1971; Pekkarinen 1979; Kesola 1998; Lehtinen et al. 1998). West of Jukajoki valley there are sand dunes of moraine as a result of the last Ice Age. The glaciers flowed lastly in northwest-southeast direction, which is the predominant positioning of water bodies within the territory of Selkie village (Lyytikäinen 1982; Kesola 1998).

In Finland the role and use of local knowledge is emerging (Mustonen 2009; Mustonen 2012a) as a field of practice, and it is connected to the debates regarding the Arctic (Stammler 2005; Watson \& Huntington 2008) and indigenous Sámi knowledge (Helander 1999; Lehtinen 2011; Mustonen 2012b). Hence it refers also to the Finnish local communities and to their subsistence activities (Luotonen 2006; Mustonen 2009). Here subsistence means fisheries, hunting, gathering and other such uses of renewable resources from a watershed that is not done for professional or monetary gain, rather for complementary and cultural purposes.

In the context of discontinued traditions of Eastern Finland and North Karelia, a more proper term than traditional knowledge is local ecological knowledge (Luotonen 2006) - here referring to those individuals that are living and habiting sites of change and who have capacities for ecosystem observations and interpretations. However this local ecological knowledge in North Karelia is not limited to a set of technical observations of birds, fish, landscapes, mires and so on. Individuals and families who have habited local communities in Karelia from pre-industrial times and are still involved in subsistence activities, such as berrypicking, fisheries, hunting, mushroom gathering and other practices continue to possess deeper readings and discourses of this place. Luotonen (2006: 204-222) provides a groundbreaking reading of a coastal Finnish local knowledge and the multi-dimensionality of Selkämeri region as a lived landscape 3 (Ingold 2000, 2004).

There is a difference between documented knowledge and oral histories. It can be summarized by saying that living oral histories (Burch 1991; Macdonald 2000; Eicken 2010; Mustonen 2012a) as opposed to documented local knowledge are communal exercises- the people themselves provide the oral matrix and transfer of knowledge that is needed to understand the wider spectrum of multi-faceted and multi-dimensional lived knowledge.

Such an act leads to an authentic representation of local community epistemologies as opposed to anecdotes, which often have been taken out of context in the documented local ecological knowledge materials. Macdonald (2000) provides a convincing case of a long-running community based oral history archive and its contextual advantages from the community of Igloolik, Nunavut, Canada. Oral histories by the communities themselves are currently largely missing from the assessments of ecosystem change and their meanings (Burch 1991; Mustonen 2012a). Toponymic and placename knowledge as a social-ecological source of information is central to this local knowledge ma- 
trix (Mustonen 2009). For the case here, the example provided by Macdonald (2000) is appropriate - the uses of the watersheds by the local populations in rural Finland are to a large extent invisible in decision-making and analysis.

According to Martinez (2011) such oral histories provide important knowledge of what has changed and how in the context of ecological restoration. Oral histories are always the product of human agency, with their flaws, faults and other possibilities for misinformation, either intentional or unintentional. However, as Burch (1991) and Macdonald (2000) remind us, potential for a more wide understanding of social-ecological systems (Berkes \& Ross 2013) is possible, if the oral histories are done with the people, as opposed to treating the locals as informants or passive targets of scholarly action. Long-term residence in the community from which the oral histories emerge also grounds them into a reflective process over several years.

Currently the human uses of the watershed of Jukajoki are to a large extent uncoordinated - they are simultaneous and layered ${ }^{4}$, some zoning on regional scale directs the process, but specifics, both from the community and ecosystem perspectives are missing ${ }^{5}$. This contributes negatively to the social-ecological systems (Berkes \& Ross 2013) in the area. A possible solution to this can be found from the recent scholarship on joint stewardship of natural resources. While recognizing the faultlines and emerging practices of models of collaborative management of natural resources (Howitt 2001; Carlsson \& Berkes 2005; Berkes 2012), especially land use and fisheries will be introduced from theoretical viewpoint and compared with the situation on the ground. More specifically the paper argues that the linear science-based readings of time and space connected with established means of watershed restoration do not address the local context adequately. Rather the local knowledge embedded in the residents of the watershed, if properly and respectfully investigated, can produce non-Euclidean time-spaces (Massey 2005, 2009) which will widen the scope, means and substance of watershed and ecosystem restoration efforts. Massey (2009) makes the case for a new understanding of open, unbounded place, such as quantum animisms ${ }^{6}$. Bridging tools can be found from the co-management regimes (Carlsson \& Berkes 2005) that take both kinds of time-space processes into account.

In terms of methodology and fieldwork thirtyfive oral histories were collected in the watershed of Jukajoki over a two-year period from autumn 2010 to November 2012. The age group included people from their 30 s to their 80 s. The interviews were conceptualized around themes related to the affected watershed and human histories around it, but allowing the interviewees to steer the conversations in the preferred direction. One-to-one interviews were paralleled with mid-size group sessions of about 5-12 people (hunters, fishermen) and larger-scale communal events with over 40 people (4 sessions). The oral history collection is a part of a larger, multi-year scientific study and restoration efforts of the watershed. Four selected documented narratives of oral histories will be used in this article to support case-relevant observations and community views.

They have been chosen as a sample because they provide narratives of traditional fisheries, ecological change and past baselines, connections with the landscape through myriad ways and lastly, opinions that are supportive of a collaborative management as a solution to the contemporary crises. Subsistence fishermen and their oral histories were instrumental in identifying the problems caused by the peat production in the first case. To summarize, these four interviews that were chosen as themes of the research come visible both in the articulation of oral history and the individuals being able to illustrate the watershed condition and impacts well, in a historical-traditional continuum.

Gender balance was proportionate with a slight emphasis on male respondents. Interviews were documented using digital recorders, transcribed in Finnish, returned to the interviewed person for a review and then stored at the Snowchange Oral History Archive, which is a community-based node of oral histories from the boreal and Arctic subsistence communities of Eurasia. The paper is driven by auto-ethnographical research as the author is the head of the community of Selkie. This village together with Alavi, the second settlement in the watershed, leads the post-peat production restoration work in the watershed.

The position of a researcher as both an actor and an analyser of events has its pros and cons. An insider view provides better access to the events and materials but also produces biases and "blindness" to issues at hand. The author is aware of these problems and has tried to identify them through this inquiry and avoid pitfalls created by such a process.

Berkes (2012) while exploring marine fisheries calls for a widespread reform of natural resource 
management in the context of rapid ecosystem change. He (2012: 466) argues that ecosystembased management (EBM) approach involves and includes a holistic view of managing resources in the context of their environment (see also Howitt 2001; Pretty 2011). It contains a consideration of habitat issues and system resilience. By identifying gaps in case studies around the world (mostly in oceanic ecosystems), Berkes (2012: 466-468) emphasizes that ecosystem-based fisheries management (EBFM) based solely on fisheries biological science captures only one slice of the EBM pie.

A broad ecosystem-based approach that includes social as well as ecological considerations has been identified as a "social-ecological system" (Berkes 2012: 466-468; Berkes \& Ross 2013), which manifests as a complex adaptive system that includes social (human) and ecological (biophysical) subsystems in a two-way feedback relationship (see also Mustonen 2012a). In short a socialecological system perspective is a major departure from the conventional view in rural Finland. In the context of Finnish resource governance, new approaches are urgently needed as the previous models of using natural and raw materials have proved to be socially and ecologically unsustainable (for example on hydroelectric power, see Mustonen et al. 2010; Mustonen 2012b). Of course equity and power problems associated with natural resources production have a global reach too (Howitt 2001; Pretty 2011).

In the Finnish (non-Sámi) context it is well known that the business as usual, for the most part, has wrecked the natural habitats and left the local communities, some of which also embrace largescale natural resources production, without a voice. Local environmental knowledge as a key source of additional and non-Euclidean knowledge regarding ecosystem change can be identified as a remedy for this context. Integrated ecosystem management, with a strong emphasis on fisheries $^{7}$ and realized through a possible co-management regime (Carlsson \& Berkes 2005) may prove to be a crucial new step in the emerging field of ecosystem restoration (Martinez 2011). It can combine the oral histories of the affected people (Mustonen 2012a) as a valid source of pre-use ecosystem characteristics ${ }^{8}$. Oral histories of living people are relevant, because as opposed to archival materials, they are a part of the agency in the watershed - actors with an active role and interest in restoration processes. The overwhelming size and speed of mire-marshland territory extraction within the last 60 years (Tanskanen 2000) provides possibilities of baseline information to be gathered from those who lived and used the little-disturbed watersheds prior to their alterations.

Berkes (2012: 470) argues that the system change, whether in terms of climate or ecosystems, requires us to address management in a whole new context of principles. The transformation from management into governance has to include a set of tools to be successful. He identifies amongst some co-management or sharing of resource use power, in some cases also adaptive comanagement, which would mean an on going, self-organised, dynamic process. Social learning, inclusive management and integrative science have been established decades ago as valid approaches to the emerging new natural conditions, but interestingly enough Berkes suggests clumsy solutions, more specifically defined as "exploratory solutions that include inputs from a broad range of stakeholders along the fishing chain and require information-sharing, knowledge synthesis and trust-building" (2012: 470). These unexpected, "fuzzy" solutions may provide new avenues for ecosystem stewardship, which Berkes identifies as being a "strategy to respond to and shape socialecological systems under conditions of uncertainty and change to sustain the supply and opportunities for use of ecosystem services to support human well-being" (2012: 470).

In the context of Jukajoki watershed, both the special natural conditions (acidic soils, phyllites) combined with severe ecosystem damages resulting from drainage of wetlands, peat production, ditches, clear cuts, extractive soil enterprises, human-altered water bodies and infrastructure construction over a period of a relatively short time (50 years) produce a context where extraordinary and new mechanisms of ecosystem restoration are needed.

Established, institutionalized land management and uses cannot provide sufficient answers any more. In this article the role of fisheries plays a crucial role as the fish have been an indicator of ecosystem degradation in 2010-2011, and a source of local knowledge for the people in the surrounding communities. Ecosystem-based fisheries management is therefore both needed and may provide new ground for restorative work in the watershed. Berkes (2012: 473) argues that EBFM is revolutionary because it would involve dealing with multiple disciplines, scales and objectives simultaneously. Addressing EBFM would 
offer the possibilities to expand management into a notion of governance that includes cooperative, multilevel approaches involving partnerships, social learning and knowledge co-production.

So if local knowledge is an important source of management in the case of Jukajoki watershed and it receives a full expression through the various oral histories from the communities, where does this lead us in terms of governing the river? The answer lies potentially in the role of collaborative management of resources which has been defined for example as follows:

- Co-management is a situation in which two or more social actors negotiate, define and guarantee amongst themselves a fair sharing of the management functions, entitlements and responsibilities of a given territory, area or set of natural resources.

- Co-management of common-pool resources, such as fisheries and forests, are depicted as some kind of power-sharing arrangements between the State and a community of resource users.

- Collaborative management, co-management, is defined as the sharing of power and responsibility between the government and local resource users.

- Co-management is a situation in which two or more social actors negotiate, define and guarantee amongst themselves a fair sharing of the management functions, entitlements and responsibilities of a given territory, area or a set of natural resources.

- It is an association of co-management with natural resources management: co-management as a partnership between public and private actors. Co-management is not a fixed state but a process that takes place along a continuum. (Adapted from Carlsson \& Berkes 2005: 65-66, see also Berkes \& Ross 2013)

From this set of definitions we can say that comanagement is therefore an approach to governance. It is a form of governance that, if properly designed, addresses the concerns identified by Ettlinger (2011) and Foucault (2005) with the notions of governance, governmentality and (ab)uses ${ }^{9}$ of power. Carlsson and Berkes (2005: 65) identify that "communities" and "the State" have many faces. Most importantly, they feel these actors need to concentrate on the function, not on the formal structure of a system. Optimistically Carlsson and Berkes (2005: 66) see management as a right to regulate internal use patterns and transform the resource by making improvements. In the Finnish context of state dominance and abuse of power in resource management (for example Mustonen et al. 2010) the co-management regime is a new concept. Only recently some initiatives have begun to emerge, for example in the case of the Sámi people and the Hammastunturi wilderness area in Lapland. However while consultation and participation have been guaranteed in the environmental impact assessments and hearings regarding various scales of resource exploitation in Finland, no meaningful power sharing or local contextualisation has taken place (Luotonen 2006; Mustonen 2012a, 2012b).

Carlsson and Berkes (2005: 66-67) identify the type of agency with which arrangements are made to be usually agency with jurisdiction over an area (usually a state agency) and local communities. Communities are rarely "coherent and homogenous units" (ibid.). They are constantly changing and they are multidimensional, cross-scale social-political units. In terms of investigations of time-space, they may contain and produce non-Euclidean narratives of a place (Massey 2005, 2009; Luotonen 2006; Mustonen 2009; Ettlinger 2011).

Carlsson and Berkes (2005: 66-67) interpret comanagement as a continuum from the simple exchange of information to formal partnership. It supposes that parties have agreed on an arrangement, but the actual arrangement often evolves. They (2005: 67-68) emphasize that it is a dynamic and iterative system, a process which is constantly re-adjusted because ecosystems and how they respond to resource exploitation may be highly unpredictable. According to them "Command-and-control kind of resource management is a poor fit for ecological uncertainty...Nature is seldom linear." $(2005: 67,68)$ Hence "the evolution of co-management networks is the substantial result of ongoing processes of problem-solving." (2005: 74). Lastly, according to Pinkerton (1989 in Carlsson \& Berkes 2005: 71), there are an identifiable number of tasks for a well-functioning co-management, which should include:

1. Data gathering

2. Logistical decisions: who harvests and where

3. Allocation decisions

4. Protection of resource from environmental damage

5. Enforcement of regulations

6. Enhancement of long-term planning

7. More inclusive decision-making

In addition I propose also new steps and methods in ecosystem and watershed-based restoration work. In the context of Jukajoki it is hard to establish a baseline view of the former 
healthy ecosystem and of the human interaction as we do have only limited written materials from the region from 1930s onwards. On the other hand we have plenty of texts regarding Finnish tradition and regional history from 1500s onwards (locally see Selkien kyläyhdistys 2004; for North Karelia, see Mustonen 2009). A successful combination of both written and oral histories combined with the innovative, "clumsy" approaches suggested by Berkes (2012) may provide new avenues of improving this social-ecological system of Jukajoki. As Martinez (2011) proposes we need alternative baseline assessments in the context of determining the scope, extent and aims of ecosystem restoration work. Firstly, old photographs of the area, and in some cases old maps, may prove to be crucial in determining the situation of low or no disturbance on the river (ibid.).

Secondly, a method which is applied in this paper, the role of documented oral histories as a (re)source of landscape restoration should not be underestimated (Martinez 2011). Ecological restoration in the context of severe damage such as in Jukajoki and Jukajärvi watersheds demands a range of innovative, extraordinary and unconventional methods (Berkes 2012) in addition to more mundane technical solutions. Oral histories can help us determine what has changed. They act as a crucial source of complimentary, and in some cases, primary vehicles of trying to determine the extent of change. Oral histories can also provide investigations into why certain change happens, and what can be done to address change. Lastly they may, if we are open to radical and differing geographical time-space discourses (Massey 2005; Mustonen 2009, 2012a), provide unique non-Euclidean views on a place (Ingold 2000, 2004; Sheridan \& Longboat 2006; Massey 2009).

Most importantly, in the context of this paper, the role of these lived oral histories provides evidence and targets for watershed restoration work as limited written records hinder a baseline assessment. Oral history can also provide a qualitative and rooted aim of a restoration work (Martinez 2011), meaning that it identifies the most important factors that need to be aimed at during such a process. Therefore the oral histories, if they get expressed in culturally-appropriate ways, may be avenues of social change in a context where local voices otherwise are dismissed in natural resources and land use debates.

\section{Four rivers across time and in time - Results from the oral history work}

The 35 collected oral histories over 2010-2012 identify a large corpus of observations, themes, traditions, counter-narratives and opinions regarding the Jukajoki and Jukajärvi watersheds. For the purposes of this article only small segments of the cultural texts from the villages of Selkie and Alavi have been chosen from the corpus ${ }^{10}$. More precisely the oral histories here consist mainly of four narrative texts ${ }^{11}$. Integrated ecosystem view has been applied, which means all human uses as well as natural processes of a watershed have been surveyed. Both written communal texts (Selkien kyläyhdistys 2004) as well as oral histories have been employed. Toponymic and place-name knowledge of the chosen people is used to demonstrate the quality and scale of local knowledge contents, but a full portrayal of this theme awaits future publication.

The oral history materials which have been collected during the fieldwork as well as the communal written texts and histories related to Selkie (Palomäki 1960; Selkien kyläyhdistys 2004) portray three "rivers" across time with a fourth reading as an emerging, non-Euclidean time-spaces (Mustonen 2009) of the river. In short they are "Jukajoki in Sámi times" [from Time Immemorial to the closure of pre-history in linear time, roughly 1500s], "Jukajoki as a Savo-Karelian River" [From 1500s of first written records through dispelling of Karelians in 1640s to 1940s], "Jukajoki as a Damaged River" [From 1940s to 2010s], and lastly, partially sitting outside these readings, "Jukajoki as a Dream River" [Communal Oral History from 1930s through to future, with prophetic and Non-Euclidean time-space qualities].

\section{Jukajoki in Sámi times}

We can characterise the Jukajoki watershed in Sámi times as having a very low human impact (Selkien kyläyhdistys 2004). The siidas ${ }^{12}$ (Aikio 1992; Helander 1999; Mustonen \& Mustonen 2011; Aikio 2012) of those Sámi Nations ${ }^{13}$ that used and occupied the watershed as a part of their hunting and fishing seasonal cycles are reflected in the regional place-name knowledge, such as in toponyms as "Eno" [a big river/rapids] (Aikio 2007; Vesajoki \& Pihlatie 2011; Aikio 2012) along the 
Pielisjoki watershed adjacent to Jukajoki. Most likely these communities were connected with the lake Pielisjärvi siida communities (Mustonen \& Mustonen 2011). By 1500s, Sámi people living in these communities were either driven further north, assimilated to the arriving Karelians or disappeared for other reasons from the watershed (Selkien kyläyhdistys 2004; Aikio 2012). This manifestation of the Jukajoki watershed social-ecological system can be characterized as having low human impact and fairly natural ecosystem health in this understanding of the landscape.

\section{Jukajoki as a Savo-Karelian river}

First written records locate the village of Selkie on maps around 1500s when the habitants belonged to Karelian culture (for summary of settlement histories see Selkien kyläyhdistys 2004; Saloheimo 2010). The river was harvested for lake-bound Atlantic salmon and other fishes and the meadows along the shores of the river were most likely important source of natural hay. Information about the land use and occupancy of these people remain vague, even though we do know some details of specific houses thanks to taxation sources.

In mid-1600s the Karelians were driven out, or according to some materials, left willingly, to other parts of Russian Empire [namely to Tver region] before the advancement of Savo-Karelian peoples from the West who belonged into the Lutheran religion attached to the Swedish Crown (Saloheimo 2010). This expansion was driven by slash-andburn agriculture called kaski, which required roughly one hectare of land per year per family for this style of farming. Fishing, gathering and hunting economies remained strong alongside foods acquired through farming. Small mills existed along the river Jukajoki (Selkien kyläyhdistys 2004). Meadowlands along the rivers were used according to family territorial use - this system had characteristics of seasonal transhumance even though the village was the primary place of habitation (Snowchange Selkie Oral History Tape 300810).

Characteristics of local ecological knowledge of these peoples were rooted in the tradition of the area. The key person in the community to possess otherworldly and cosmological information was the tietäjä, "he who knows" (Mustonen 2009). "Power of nature flowed through him" has been one oral history by which such people were described in the North Karelian communities (ibid.).
As our focus is on the wetland uses of the area of Jukajoki, the oral histories of an 80-year-old male describe the mires in the following:

"The mires were far wetter before. It caused the lake great damages when the ditches were made and mires drained to the lake - these waters went straight into the lake. It caused great damages. They used to be cloudberry mires, and we of course went there constantly."14 (Snowchange Alavi Oral History Archive 171012)

Jukajärvi lake and Jukajoki were sources of lake iron in the late $19^{\text {th }}$ Century, more precisely the activity started in 1860-62. This iron oxide was produced into iron in the region. It is mostly located in 1-3 m depth. All ore was taken by hand. On Jukajoki River a small smelter produced chunks of iron from the natural ore. Its capacity was for approximately $1020 \mathrm{~kg}$ of ore in 24 hours. Iron was mostly used to make everyday items for the small farms in the region. In 1862 in total 42500 $\mathrm{kg}$ of iron was produced but already in 1865 the amounts went down to $3400 \mathrm{~kg}$. This enterprise was discontinued in 1865 (Selkien kyläyhdistys 2004: 21).

Fisheries have been and continue to be a crucial subsistence activity in the watershed. In earlier times they provided food security for the communities and even today remain a source of cultural and subsistence harvest. The land-locked Atlantic salmon came up the Jukajoki River in 1930s, providing to be a key indicator of a healthy river (Snowchange Selkie Oral History Tape 300810; Vesajoki \& Pihlatie 2011). Hydroelectric power stations and subsequent ecological damage has discontinued these habitats (Vesajoki \& Pihlatie 2011).

Oral histories from an 80-year-old man on lake Jukajärvi provide a view to the fisheries in 1930 s and 1940s:

"I have memories being 10-years old fishing with my grandfather, the father of my father... He used to walk to the lake with a walking stick and I was the rower. My cousin was there and my little sister Liisa, always were together...We made the nets ourselves. The spawning times of bream [lat. abramis brama] was our main fishery prior to midsummer and at the time of midsummer the big breams came to spawn close to the shore and then we got them. Two-three kilogram fish. Our neighbour made so-called ancient fish traps from strips of pinewood. Spawning times of the fish were known well, smaller bream spawned prior to midsummer and on midsummer the big breams 
started to spawn... When we got the big breams our boat bottom was covered with them, we never had to go to fish and return empty-handed, I do not recall we ever came back empty-handed."

(Snowchange Alavi Oral History Archive 171012)

The Savo-Karelian times along the river started to display impacts from the human uses, but both oral histories and written texts (Palomäki 1960) indicate that this level of disturbance remained fairly low or took place in the context of subsistence farming, fisheries and small-scale harvest of timber. Iron harvest towards the end of $19^{\text {th }}$ century represents one of the first larger-scale harvests of natural resources from the watershed. But things were about to change towards the end of $1930 \mathrm{~s}$ and 1940s with the WW2 looming on the horizon.

In terms of socio-ecological system there was a great shift in late 1940s when families arrived from the ceded Karelia after the Continuation War and were re-settled along the Jukajoki river (Palomäki 1960). They cleared new fields and farm sites from the forests in the watershed. Then in 1959 the local farmers with state agencies supporting them decided to lower the water levels on lake Jukajärvi for the third time. The purpose of the act was to receive new farmlands from the emerging lake bottom. This was partially successful. However the process had great consequences for the whole watershed below Jukajärvi. Also impacts to the fishery in the lake and river were tremendous. It is clearly a key marker in the past 100 years in the ecosystem. Subsistence fishermen resisted this draining of lakes as is evident from one oral history by a male, 80 years old:

"A piece of paper was circulated in the village where you had to sign your agreement, indicating that you approve of the draining of the lake. I recall my father and a certain Vartiainen...they did not sign the paper even though they went through whole village all the way to Pyhäselkä to collect signatures...There was a need for farmland then. That was the primary reason and it caused benefits to a certain family, they could now make a new road that they could use. They had to travel through the forests prior to the road. Those that signed the letter approved of it. My father and Vartiainen did not protest further but they refused to sign this letter, as they were suspecting that there would be no more fish in the lake as a result. The people from the villages of Heinävaara, Särkivaara and Alavi approved it and then they made needed changes to the river Jukajoki, digging the river up and so forth... and then the waters started to move, it was wintertime. Ice was left on air as more water was drowned out from the lake than was planned...We went to see it and wondered... It caused negative changes as the shoreline we used to have was real good and it was wrecked... At first it was ok, but then water plants and mud arrived to the shores and you could not swim there....Fish disappeared completely after the draining. I do not know if they went to river Pielisjoki or where...Slowly they started to make a comeback and new stocks were brought also from small lakes from Heinävaara, mostly perch and roach which was caught by the local fishermen with a fish trap and brought here..."

(Snowchange Alavi Oral History Archive 171012)

Breams ${ }^{15}$ which were introduced to the lake after the 1959 draining have started to reproduce rapidly, as is evident in the observations made by one subsistence fisherman, 58-year-old from Alavi:

"Those that are still trying to catch bream have noticed it has become really small. When the lake lost its fish it was a great mistake then to reintroduce bream there in those numbers as the lake is so eutrophic that it is an ideal environment for the bream."

(Snowchange Alavi Oral History Archive 220612)

Place names and toponymic knowledge along the watersheds was still mostly in its oral form. They reflected the Savo-Karelian land use and seasonal rounds, where hunting, gathering and fisheries formed crucial subsistence activities. They were recorded on Finnish maps by the state cartographers in the $20^{\text {th }}$ century. These toponyms provide crucial indicators of ecosystem health when combined with the oral histories. As an example of such a process two place names are discussed here. "Hirviniemi" means "Moose Cape", an area through which the moose crossed the lake Jukajärvi on their way to their winter pastures - a cycle that had been in place most likely since post-glacial times. Information about this toponym is provided in the narrative of a subsistence fisherman, 58-year-old from Alavi:

"Hirviniemi.... when I moved here there used to be a lot of moose here on the move as there was very little human habitation on the opposite shore. The lake used to have a real strong bottom here and it could hold the weight of a moose. In summertime large herds crossed here too. I could see them when they came and ate and then they went over to the Särkivaara area. They fed themselves here, large herds. But then when human habitation increased on the cape the natural crossing point was abandoned. Now they have to go around the lake, 
and cross the road to Ilomantsi, which means a lot of car crashes on the road. There is a tremendous amount of moose tracks here and territories where there is food, food for them and peace. These are good wintering grounds for them. Around mire Valkeasuo they had an aerial surveys for herds and they could spot 200 moose at once on these wintering areas. And towards Riuttavaara it is a good area for calving too."

(Snowchange Alavi Oral History Archive 220612)

Further north as a part of this hunting-gathering subsistence economy the toponym "Linnunsuo" [Marsh of the Bird] had been allocated to a marshland, which is situated along the Jukajoki River and adjacent watershed. This toponym is based on the central role of capercaillie (lat. Tetrao urogallus) and black grouse (lat. Lyrurus tetrix) in the subsistence hunting complex ${ }^{16}$ (Berkes 2009) for the villages of the region. A famous ethnographer R.E. Nirvi who worked in the villages in early $20^{\text {th }}$ Century documented that in the local dialect the marsh was called "Linnonsuo" (Nirvi 1974: 977). The marshland was a crucial moose hunting and berrypicking area too (Snowchange Selkie Oral History Archive 2010-2012). Nirvi also confirms the locals considered this place to be a crucial berrypicking area (Nirvi 1974: 977). This area was wrecked by the peat production started in 1970s and 1980s (Vesajoki \& Pihlatie 2011; VAPO 2012). We can establish that the end of the period for Jukajoki as a Savo-Karelian River took place around 1930 s.

\section{Jukajoki as a damaged river}

Due to the massive changes in society ushered in by the war and subsequent state-sponsored industrial land use projects from 1940s to 1990s (Tanskanen 2000), the Jukajoki also was impacted by these developments. Most of the mires were drained, amount of discharge from ditches for forestry altered water quality and peat production changed whole water regimes on Linnunsuo mire. Additional impacts came from the hydroelectric stations that were constructed along the river Pielisjoki (Vesajoki \& Pihlatie 2011). As a result, the time when it was still possible to fish Atlantic salmon and trout along the river came to an end.

In the 2000s the state-owned energy company VAPO produced peat in the former mire of Linnunsuo. On $17^{\text {th }}$ July 2010 a local subsistence fisherman living in Tiittala [a part of village of Selkie], along Jukajoki observed four dead fish floating down the river (Snowchange Selkie Oral History Archive 220710). Observation was made three km downstream from the VAPO production site. On $18^{\text {th }}$ July 2010 far more dead fish were seen and a large flock of seagulls flying back and forth along the river, eating the dead fish. The acidic discharges from the production site killed all the fish in the river downstream from the VAPO site both in 2010 and 2011. These damages bypassed the monitoring regimes of the company and the state environmental authorities. The local knowledge of the fishermen still made relevant observations, 50 years into the large-scale alteration of landscapes and watershed by humans.

Case samples of the oral histories from this period illustrate the scope and quality of knowledge today. How do the people living in the contemporary times conceptualize this watershed and how are skills learned? Answers can be sought from an oral history of a 58-year-old fisherman:

"We fished for burbot a lot, also with fish traps actively. We tried those old spots harvested by the old people, we asked where they had been fishing."

(Snowchange Alavi Oral History Archive 220612)

This excerpt from the oral history account is relevant for a number of reasons. The Finnish communities and peoples have often been identified as having lost their traditions through the modernisation process in our country (Mustonen 2009). Here something remains. First off, the people are still targeting a non-game species, the burbot using fish traps. Secondly they are harvesting spots passed on from the "old people" and they have actively sought these spots and sources of oral knowledge themselves. As long as the subsistence activities, such as fishing persist, so do remnants of the larger body of local knowledge.

Building on this surviving body of knowledge, emerging observations of ecosystem health can be gathered. For example a 58-year-old fisherman shares his observations about the lake Jukajärvi. The lake suffers from the discharge of organic matter from several dozen forestry ditches:

"In the deep spots and on the edge of the deep people have tried to fish and have noticed that there seems to be a lack of oxygen in the winter, not even pike perch persists there. In the summertime the nets become so slimy that I do not really have an interest to fish there anymore."

(Snowchange Alavi Oral History Archive 220612) 
Another excerpt by him addressed the discharges from the drained mires and their impact on lake Jukajärvi, portraying the baseline information that Martinez (2011) supports too:

"I am wondering as I used to set nets here on my shore, perhaps ten years ago, I was using nets which were at least two meters tall. Now there is not even that much water there, perhaps one meter twenty centimetres."

(Snowchange Alavi Oral History Archive 220612)

The same fisherman, known for his skills in the community of Alavi, commented on bream in his narrative:

"Then it is a time when the bays are sloshing when big bream fish come to spawn, they are midsummer bream, it comes around both sides of midsummer. The water temperature affects it and also air needs to be still and hot, over $25^{\circ} \mathrm{C}$. When the air is still you can see their fins. There is not a lot of bream and when nets become dirty so easily we do not fish them so much."

(Snowchange Alavi Oral History Archive 220612)

This narrative is relevant for a number of reasons. Again, traditional calendar built around bream spawning times and harvests seems to have been passed on from the people who mastered it in the 1930s (see Snowchange Alavi Oral History Archive 171012) despite the modernization process. Secondly the knowledge contains information about seasonal marker (midsummer), water temperature (over $25^{\circ} \mathrm{C}$, in Finnish helle) and wind (it needs to be still). Lastly optic history ${ }^{17}$ is used to confirm that the big bream fish enter the bays ("you can see their fins").

During the times of damaged watershed another human impact was restocking. A male fisherman in his 60s observed that:

“Until 2008 or 2009 and when pikeperch started to flourish in the lake due to restocking, we used to fish with winter nets in the deep parts of the lake...Across the deep part. Then we started to wonder as the nets were three meters tall and in the lower part, perhaps for a half a meter or a meter, a brown rust colour emerged. We could not wash it off with anything. Usually we checked nets once a week and if there was a pikeperch on the lower part of the net and it had gone into the bottom mud its gills and mouth were filled with this rust goo."

(Snowchange Alavi Oral History Archive 130912)
In this narrative fisherman has identified the restocking as a source of subsistence fishery. He continued the winter net fishing and made observations of the deep part of the lake, more specifically about a phenomenon of emerging goo from the deep. It had impacted pikeperch caught in the nets. Regarding other species, observations of birds can be seen in the following narrative by a male, 58 years old:

"I went to the shore where the pier is and duck had ducklings there, eight of them. Swans, usually two pairs. There was a crane and a swan nests close to each other here in the bay of Iso Rapalahti. But some autumns ago swans stopped here on the bay and I am not lying, they must have been in their thousands...the bay was all white. Last Autumn this was not the case however."

(Snowchange Alavi Oral History Archive 220612)

Some of the fishermen along the watershed have observed events and phenomena that they cannot explain easily, as is the case in a narrative told by a fisherman in his 60s:

"I went to fish towards Kissapuro creek and it was a still morning. To my big surprise I heard kind of splashing, water splashes, and I was thinking it must be breams spawning. Then I rowed closer and I noticed that a bay covered with weeds and grasses produced these great bubbles of air."

(Snowchange Alavi Oral History Archive 130912)

In this oral history fisherman is visiting an area he knows well. Sounds are heard and he positions them to the seasonal event for the bream spawning. To his surprise this is not the case, as it is unexplainable bubbles emerging from the lake bottom to the surface. The polluted waters contrast with the memories from the deep knowledge of a cleaner watershed.

The surviving local knowledge systems act as a pool of self-reflection too. An 80-year-old fisherman, who also worked as a farmer from the 1940s to 2010 s, says regarding the draining of mires and creation of ditches that:

"I believe some kind of a matter has flowed from the forests, and I have to confess that I have played a part in it too myself... as the waters have flowed through my fields and we have used fertilizers to make them fertile. These fertilizers are accumulating and start to grow hay on the lakeshores, and then waves bring these substances to the shores... it was not there when I was a child...It used to be clear sandy beaches, now there is soft and muddy 
materials in meters at the bottom, in my shore over four meters deep, they say those researchers who have made drilling samples there."

(Snowchange Alavi Oral History Archive 171012)

This part has focused on surviving elements of local knowledge in the context of Jukajoki as a damaged river and watershed from 1930s to 2010s. Subsistence fishermen continue to make observations that have relevance for the whole river and lake. They also observe throughout their fishing areas anomalies like the lack of oxygen, presence of iron, and unexplainable chemical processes in the form of bubbles. Lastly those in the community who lived through the state-sponsored alteration campaigns of ecosystems, especially mire drainages, reflect on the damages and position themselves as a part of the problem, admitting that mistakes were made.

\section{Jukajoki as a dream river}

Three readings of rivers embedded in the local knowledge have been identified and categorized according to the amount of human impacts the watershed has received. Lastly, an element of the local ecological knowledge that contains multiple "time-spaces" is explored.

During the oral history documentation work some of the older ladies (in their 70s to 80s) in the villages were interviewed. These women from the lake and riverside spoke openly about what has been called with various terms, including "sacred", "hidden" or "mystical" elements that local knowledge may have. For example the role of dreams as an information tool to know about things to come is central to this process. Sheridan and Longboat (2006) as representatives of Indigenous societies have ventured the furthest in academic literature and made the claim that instead of forming "socio-ecological systems", those humans with rooted connections with their home areas belong to those places - meaning there are connections that exist beyond the Euclidean (Ettlinger 2011) readings of time and space.

Such elements are present in one oral history we recorded in late summer 2010 when the damages were most pronounced. This older woman from the village of Selkie is known in the region for her knowledge of the local tradition. She fished for salmon as a young girl with her father in 1930s. Through 1930s to 1950s she was able to meet and listen to the oral knowledge from one of the last publicly known tietäjä, a spiritual person of Selkie, who lived in Palovaara. She told $\mathrm{me}^{18}$ :
I was remembering Jukajoki and all those experiences that came to my mind, and then I saw this dream the other night, and in this dream we were walking along the river...It was on the meadow [next to the river], to the right at the bridge, towards river Pielisjoki. I do not remember who was with me. Perhaps my father or someone else. The meadow had turned into humus, turned upside down, it was no longer a meadow. And this river Jukajoki was as narrow as it is today for a stretch of one kilometre. But [the river] was filled up with soil or with some kind of mud which had dried up there. All of a sudden the river widened up into its former width and there was a sandy bottomthough no water at all. And in such form it flowed to the river Pielisjoki. I remember also in the dream that I became so glad when I saw that there was sand and that the river is wide again; I gave a shout in the dream, that there is sand here! And thus it ended.

(Snowchange Selkie Oral History Archive 300810)

While the more specific meanings of this event will remain within the community, what is noteworthy is that as this oral history demonstrates the people and the river have very sensitive and intimate connections that can manifest as dreams. The old woman sees the different stages of life of the river from the salmon stream, through the damages of today into things that are perhaps yet to come, a sandy, wide, healthy river. Such power stories of intimate connections that local people may have demonstrated that their knowledge is not only a set of observations. Instead it can be read as a wide-ranging "cosmovision" where past, present and possible futures create non-Euclidean (Ettlinger 2011) renderings of time-spaces that need to be assessed carefully and within their cultural matrixes.

\section{Conclusions - Integrated ecosystem management in heavily damaged post-industrial watersheds in Finland through co-management}

Lastly the questions of management of the watershed were explored in the corpus of the 35 oral histories collected between 2010 and 2012. Local people of Alavi and Selkie have witnessed, as is evident, the events, which have happened, they have been involved in some of them through workforce (Snowchange Alavi Oral History Archive 171012) or instigators of change (ibid.) as is the case with lowering the waterlevels of lake Ju- 
kajärvi. They have also witnessed impacts from imposed industrial uses of land as is the case of fish deaths as a result of peat production. How do they then think of "integrated ecosystem management" in heavily damaged areas in their own terms?

In those oral histories that are presented here, answers range from a set of technical-land use decisions into governance. The former is present in the narrative of a male, 58 years, from Alavi:

\begin{abstract}
"In my view it would be most important to tackle the existing ditches that have been done back in the old days, the forest and mire draining, they should be the target of the first set of actions. There should be proper dam structures and lessening of water flow to the extent that that organic matter, the solid matter in the flow, would stay in the pools of the dams... Regarding the field zones, there should be protective zones that are mandatory today, the pressure coming from the watershed to the lakes should be fixed, and then we could start to consider the water levels, dredging and cutting hay, and fishing for 'coarse fish', if there was a need, and that is about all there is to it..."
\end{abstract}

(Snowchange Alavi Oral History Archive 220612)

In this view the local man positioned the role of surrounding watershed as a primary target of restorative actions prior to actions on the lake and river itself. Instalment of dams to control the organic and solid matters flowing from the ditches and the proper zones to the fields could control the damages according to him. Dredging and other management options on the lake would only come later.

In another narrative a male subsistence fisherman in his 60s linked governance (Ettlinger 2011) to the responsibility that both society and the local communities have:

"Around the lake there are several villages and
joint management would presuppose good and
clear cooperation between these communities...
perhaps if there was a joint cooperative body to
which representatives of different villages would
be chosen to...I do not know what such govern-
ance would mean to us if it became... but at least
it would mean that this [cooperative body] would
collect information and observations about the
lake and would see a range of uses and values for
the lake... A joint land ownership... what would
be the economic building blocks for such a thing
or to a governance...It is a process we ought to
consider and think about. But all in all the future
of the lake depends on funds from society at large to repair this lake, because those that have caused all of this remain active in the watershed and society has received funds through their activities, such as through forestry...A joint responsibility should be clear in the sense that the impacts are taken care of too, all of what they have caused. It is almost the same, we can compare this to the large sawmill sites in North Karelia or former gas stations... in those locations the environment was totally ruined due to the company and what they did, so in fact it is the society that has to pay for these impacts. We can make a direct comparison to here, this environment has been heavily used and we can see the impacts here, I cannot believe the local people would have the financial resources to correct these results by themselves."

(Snowchange Alavi Oral History Archive 130912)

In this oral history there are several key concepts that link almost precisely to the definitions of a co-management regime proposed by Carlsson and Berkes (2005). Firstly the person identifies the need of the villages to be in close proximity to each other. Secondly he drafts an organ that would be a joint representative body in a future arrangement for cooperative management. However he has no experiences from such events so he is not yet quite sure what does it mean but at least it should collect "information and observations", referring to both science and local knowledge of oral histories. Lastly the person identifies responsibilities, saying that the local people cannot possess resources for the damages caused by the industrial activities.

Carlsson and Berkes (2005) identified the comanagement of a given territory as a power-sharing arrangement. Berkes (2012) while discussing fisheries called for "fuzzy" and "clumsy" solutions on the basis that ecosystem change, including impacts of climate change (Arctic Council 2005), require us to think outside the box. The local oral histories collected from the local people in the empirical materials link autonomously similar needs for the Jukajoki watershed and go on to identify how it should be organised and providing mandates for local knowledge observations to be included in the valid sources of decisions regarding this area. They reposition a village as an actor regarding its lands, manifesting traditional governance through possible co-management arrangements. Importantly enough such proposals emerge from the oral histories of people living in ecosystems, or socio-ecological systems that have been affected by a full range of modern and industrial activities, causing severe damages. It means that 
the communal arrangements and knowledge regarding the watershed has lasted through the various stages of this process and are re-emerging, again strengthening the argument for non-Euclidian readings of time-space if viewed from the grassroots subsistence level.

\section{Discussion}

The purpose of the paper was to explore (mis-) management in the context of severe ecosystem damage on the river Jukajärvi and adjacent watershed. More specifically, questions emerged on what are the possibilities that Finnish local knowledge embedded in oral histories can provide as a source of information both on current events and as a baseline material for restoration actions? Secondly, in the light of international scholarship, what are the needs and advantages for a collaborative management of Jukajoki?

This article has explored local oral histories and selected communal written texts and their role in the severely damaged watershed of Jukajoki [and adjacent lake Jukajärvi watershed] located in Kontiolahti and Joensuu municipalities, North Karelia, Finland. All in all 35 narratives were collected 2010-2012. Four narratives have been presented in this paper as an example of the materials. Empirical materials have been analysed using the framework of both integrated ecosystem management and co-management proposed by Carlsson and Berkes (2005) and Berkes (2012). Three readings of the river Jukajoki and the adjacent watershed emerged from the materials - Sámi times, Savo-Karelian times and times of damages, or the industrial age on the river.

In the case of Jukajoki, the local knowledge played a crucial role in detecting fish death, and as the oral and optic histories were documented between 2010-2012 many additional observations on health of watershed were discovered. It provided information about pre-industrial fisheries, fish ecology and behaviour and bird habitats. The oral histories contain non-Euclidean, or specific categories and ways of discussing the area and species. Such cultural texts range from spawning times of bream fish as an indicator of lake use into intimate, mystical connections in dreams regarding the river. These are, as indigenous scholars have proposed (Sheridan \& Longboat 2006) as an intimate interconnection between nature and rooted human societies possibly extending beyond no- tions of social-ecological systems (Berkes \& Ross 2013).

Empirical oral histories also conceptualized collaborative management with a formal role of local ecological knowledge as a future management option for the Jukajoki watershed. Watershed restoration and baseline information it needs benefits greatly from the oral histories recorded with people who still remember pre-industrial and pre-war ecosystems and their qualities, as suggested by Martinez (2011). The current times with multiple, layered interests for the area of the watershed need to be coordinated better to avoid further damages, and collaborative management could be developed to achieve that goal.

Berkes (1999, 2012) highlights local or traditional knowledge as being a crucial basis for such systems of collaborative management and inclusion of a larger knowledge base in fisheries. Many of the examples he draws on such as Sub-Arctic Canada (ibid. 1999), marine fisheries and tropical regions discuss mostly indigenous populations which position their knowledges in a marked difference with the mainstream or state expert knowledge. Often also the land base and uses of these communities differ from the mainstream society.

In the case of Eastern Finland, exportability issue emerges while applying the frameworks of Berkes (1999) and colleagues (Carlsson \& Berkes 2012). The ownership of land, composition and role of kylä-communities in rural Finland and the invisibility of subsistence and even commercial fisheries (Mustonen 2009) practices in relationship to the state decision making provide an exciting, emerging inquiry filled with tensions, expectations and possibilities ${ }^{20}$. For the future, next steps of investigating the role and scales of local knowledge in Jukajoki point to a need of a land use and occupancy mapping, as this could be a potential tool to bring forwards the "unseen" realities from ground up. While maps are always limited, two-tothree dimensional representations of a much wider multi-dimensional reality, they are a tool that administrators and companies understand.

Lastly the use of oral histories may (Macdonald 2000) provide us with radically new and relevant readings of nature and human societies, which allow more sustainable societies to emerge. For Eastern Finland, this potential should be explored in a systematic manner for a wide range of communities engaged in subsistence uses of land. As a resident of the Jukajoki watershed, the oral history and ecological restoration work along the river and 
lake has been a tremendous journey into a landscape pulsating with lived (Ingold 2000) stories, human experiences and our living tradition, so often pronounced dead.

\section{NOTES}

${ }^{1}$ Majority of watershed and post-peat production restorative actions in Finland rest on natural sciences-based options. See e.g. Pellikka (2001).

2 This document, a village book, contains both summaries of scientific studies of the natural conditions in Selkie, as well as stories, reflections, poems and songs written by the villagers. The latter group represent "communal texts" - materials authored by the residents in the village.

${ }^{3}$ This statement emphasizes the need to experience, with various senses, the places of dwelling and occupancy as opposed to seeing them as linear timespaces.

4 To name a few overlapping processes, a copper and gold mine exploration licence has been provided on an area that contains protected areas, fisheries, forestry zones, a village habitation of Heinävaara, hunting territories, a railroad and so on. Furthermore, all industrial uses of the land are built on rather Euclidean notions of time-space.

${ }^{5}$ Priority, in the form of publicity, public support and infrastructure is given often to large-scale natural resources extraction land uses over other activities in North Karelia.

${ }^{6}$ Here the non-euclidean space refers to multiple, culturally-grounded understandings of places in space, which are not bound (Massey 2009). They may manifest in and through dream experiences, altered states of consciousness, long-term experiences with a river through fisheries and so on. Most importantly, they put the emphasis on the groundedness of the human experience of space (Ingold 2004). I am arguing that the local oral histories focusing on relationships with watersheds from on-going village life in Eastern Finland is to a large extent unexplored, exciting representation of a time-space that needs to be further investigated. It contains continuums of tradition in the middle of lost traditions of Finnish society, such as the role of dreams in connection with a landscape.

${ }^{7}$ Both commercial and subsistence in the case of Jukajoki.

${ }^{8}$ Other innovative materials can include old maps, aerial and other photographs, written historical narratives, catch records or diary entries. In Finland the ecological restoration plans tend to lead towards natural sciences with oral histories dismissed as "anecdotes" or supplementary data (see Mustonen et al. 2010).

${ }_{9}$ Use and/or abuse of power depends on the point of view. Those in power, when using it, may produce results in the targets of power, if this relationship is asymmetrical and without checks and balances. The local communities in rural Finland have very little possibilities to contribute to uses of power within village territories (kylä), as there is no legal context for it. Villages are only represented through third sector associations.

10 The full oral history corpus regarding Jukajärvi and Jukajoki watersheds is located at the Snowchange oral history archive, www.snowchange.org as well as the affected individuals. All in all the corpus contains over 1,000 pages of documented oral histories from July 2010 to December 2012. Cultural texts here include oral histories, diary entries from the villages, written lay texts and other narratives, which emerge in the local context and community. 11 They have been qualitatively chosen based on the information related to past fisheries and tradition, relationship with landscape and watershed and lastly, thoughts for the better management of the ecosystem. This choice reflects the role Martinez (2011) puts on those oral histories, which are relevant for a comprehensive ecosystem assessment, leading to restoration. These texts are not exhaustive, others could have been chosen.

${ }^{12}$ Siidas were and to certain extent still are the Sámi indigenous tribal communities prior to large-scale colonial influences. They had specific territories, and governance bodies, such as the Eastern Sámi sobbar village council.

13 Aikio (1992) makes the case of multiple Sami "nations" in this part of Finland - however, no historical records exist to confirm or deny this claim. If compared with other existing, specific Sami peoples, it seems clear that "nations" could exists side-by-side within a fairly small territorial base, see more for Eastern Sámi siidas in Mustonen and Mustonen (2011).

14 The oral histories are available as transscripts and and audio tapes from the author in Finnish.

15 The Finnish local fisheries are organised as osakaskunta - local fisheries bodies consisting of local people who can decide issues related to permits and stocking, for the most part. They have very limited powers.

${ }^{16}$ Knowledge-practice-belief complex as defined by Berkes (1999). However the questions of belief aspect of the knowledge apparatus require further research in the Eastern Finnish communities and await future research.

17 Optic histories are an exciting and emerging field of engagement with subsistence and other fishermen on their observations of ecosystem change. Mustonen and Feodoroff (2013) provide a number of definitions and uses of the term - it refers to visually observed events narrated using oral history, but also to digital photos taken by practitioners themselves on their terms of change that they position as meaningful. Ingold (2004) hints at this direction with the emphasis on felt and grounded experiences as a source of information.

${ }^{18}$ I have reviewed the use of this sequence of her 
oral history in detail with her for public use several times and she has approved it, saying that it is important these issues are discussed too.

${ }^{19}$ Peat production, forestry and gravel companies.

${ }^{20}$ In Finland the role and scales of local knowledge embedded for example in fish harvest data is mostly located in the Sámi areas. Differences between lo$\mathrm{cal}$ and indigenous knowledges in Finland have been discussed in Mustonen and Feodoroff (2013). In short, the Sámi knowledge contains elements of surviving ways of cosmologies and interactions with nature that have for the most part been broken in the Finnish communities as communal exercises. To what extent such knowledge and practices can be revived, see more the Conclusions section in Mustonen (2009).

\section{ACKNOWLEDGEMENTS}

This article has been made possible by the Turvetuotanto ja vesistövaikutusten hallinta: Relevanteista faktoista tehokkaisiin normeihin/WATER MANAGEMENT AND PEAT PRODUCTION: From the Relevant Facts to Effective Norms (WAPEAT) (Suomen Akatemian hanke 263465) Project. I am thankful to the two anonymous reviewers who provided crucial comments to the manuscript. I am also thankful to Dennis Martinez, Kaisu Mustonen, Ari Lehtinen, Hilkka Heinonen, John Macdonald, Pirkko and Veikko Siltala, Leena Leskinen and Terho Törrönen as well as all the interviewed people for their helpful contributions to the framing and writing of the text.

\section{REFERENCES}

\section{Oral Sources}

File Snowchange Selkie Oral History Archive 220710. Male, age 50 years.

File Snowchange Selkie Oral History Tape 300810. Female, age 80 years.

File Snowchange Alavi Oral History Archive 220612. Male, age 58 years.

File Snowchange Alavi Oral History Archive 130912. Male, in his 60s.

File Snowchange Alavi Oral History Archive 171012. Male, 80 years.

Martinez D 2011. Head of the indigenous peoples ecological restoration network. Interview, 25th September, 2011. Sevettijärvi, Finland.

\section{Written Sources}

Aikio S 1992. Olbmot Ovdal Min - Samiid Historja 1700-logu radjai. Ohcejohka, Girjegiisa.

Aikio A 2007. The study of Saami substrate toponyms in Finland. In Pitkänen R \& Saarikivi J (eds). The borrowing of place-names in the Uralic languages. Onomastica Uralica 4, 159-197. Debrecen, Helsinki.

Aikio A 2012. An essay on Saami ethnolinguistic prehistory. In Grünthal R \& Kallio P (eds). A linguistic map of prehistoric Northern Europe. Suomalaisugrilainen seura, Helsinki.

Arctic Council 2005. Arctic Climate Impact Assessment. <http://www.acia.uaf.edu> 19.10.2013.

Berkes F 1999. Sacred ecology - Traditional ecological knowledge and resource management. Taylor \& Francis, Philadelphia.

Berkes F 2012. Implementing ecosystem-based management: evolution or revolution? Fish and Fisheries13,465-476. http://dx.doi.org/10.1111\%2Fj.14672979.2011.00452.x.

Berkes F \& Ross H 2013. Community resilience: Toward an integrated approach. Society \& Natural Resources: An International Journal 26: 1, 5-20. http://dx.doi.org/10.1080/08941920.2012.73660 5.

Burch E 1991. From skeptic to believer: The making of an oral historian. Alaska History 6: 116.

Carlsson L \& Berkes F 2005. Co-management: Concepts and methodological implications. Journal of Environmental Management 75, 65-76. http:// dx.doi.org/10.1016\%2Fj.jenvman.2004.11.008.

Eicken H 2010. Indigenous knowledge and sea ice science: what can we learn from indigenous ice users? In Krupnik I, Aporta C, Gearheard S, Laidler G \& Holm L. SIKU: Knowing our ice - documenting Inuit sea-ice knowledge and use, 357-376. Springer, New York.

Ettlinger N 2011. Governmentality as epistemology. Annals of Association of American Geographers 101: 3， 537-560. http://dx.doi.org/10.1080\% 2F00045608.2010.544962.

Foucault M 2005. Tiedon arkeologia [L'archéologie du savoir]. Vastapaino, Tampere.

Helander E 1999. Sámi subsistence activities: Spatial aspects and structuration. Acta Borealia 2, 7-25. http://dx.doi.org/10.1080\%2F08003839908580495.

Howitt R 2001. Rethinking resource management: Justice, sustainability and indigenous peoples. Routledge, London.

Ingold T 2000. The perception of the environment: Essays on livelihood, dwelling and skill. Routledge, London.

Ingold T 2004. Culture on the ground: The world perceived through the feet. Journal of Material Culture 9, 135. http://dx.doi.org/10.1177/1359183504046896.

Kesola R 1998. Suomen geologinen kartta 1: 100000, lehti 4242 Eno. Enon kartta-alueen kallioperä. Geologian tutkimuslaitos. 
Lehtinen A 2011. From relations to dissociations in spatial thinking: Sámi 'geographs' and the promise of concenctric geographies. Fennia 189: 2, 14-30.

Lehtinen M, Nurmi P \& Rämö T 1998. Suomen kallioperä - 3000 vuosimiljoonaa. Suomen geologinen seura, Jyväskylä.

Luotonen E 2006. Vapaa-ajan kalastajan Oura. In Häyrynen M, Luotonen E, Mustalampi E \& Bruk E 2006. Tuntematon saaristo - Selkämeren saariston eletty maisema, 204-222. Otava, Helsinki.

Lyytikäinen A 1982. Pohjois-Karjalan harjumaiseman kehitys sekä nykyisen tilan ja maankäytön yleispiirteet. Valtakunnallinen harjututkimus, raportti 22, Joensuu.

Macdonald J 2000. The arctic sky - Inuit astronomy, starlore and legend. Royal Ontario Museum, Toronto.

Massey D 2005. For space. Sage, London.

Massey D 2009. The possibilities of a politics of place beyond place? A conversation with Doreen Massey. Scottish Geographical Journal 125: 3-4, $401-420 . h \operatorname{tp}: / / \mathrm{dx}$.doi.org/10.1080\% 2F14702540903364443.

Mustonen T 2009. Karhun väen ajast-aikojen avartuva avara. University of Joensuu Press, Joensuu.

Mustonen T, Mustonen K, Aikio A \& Aikio P 2010. Drowning reindeer, drowning homes - Indigenous Sámi and hydroelectricity in Sompio, Finland. Snowchange Cooperative, Kontiolahti.

Mustonen T \& Mustonen K 2011. Eastern Sámi Atlas. Snowchange Cooperative, Kontiolahti.

Mustonen T 2012a. Rebirth of indigenous Arctic nations and polar resource management: critical perspectives from Siberia and Sámi areas of Finland. Biodiversity 14: 1, 19-27, http://dx.doi.org/1 0.1080/14888386.2012.725652, 2012.

Mustonen T 2012b. Kohti saamelaistutkimuksen uutta tulkintakehystä. In Lehtola V-P, Piela U \& Snellman H. Saamenmaa - Kulttuuritieteellisiä näkökulmia, 254-264. SKS, Helsinki.

Mustonen T \& Feodoroff P 2013. Ponoi and Neiden collaborative management plan. Snowchange Cooperative, Kontiolahti.

Nirvi R 1974. Kiihtelysvaaran murteen sanakirja IV. Joensuu: Karjalaisen kulttuurin edistamissäätiö.

Nykänen O 1971. Suomen geologinen kartta 1: 100000, lehti 4241 Kiihtelysvaara. Geologian tutkimuslaitos.
Palomäki M 1960. Post-war pioneering in Finland with a special reference to the role of the settlement areas. In Smeds H (ed). Three Faces of Finland - Guidebooks Prepared for the Three Finnish Excursions at the XIX International Geographical Congress. Fennia 84, 43-68. Finnish Geographical Society, Helsinki.

Pekkarinen L 1979. The Karelian formations and their depositional basement in the Kiihtelysvaara-Värtsilä area, East Finland. Geological Survey of Finland, Bulletin 331.

Pellikka P 2001. Suopohjat kierrätykseen - mitä tehdä vanhoilla turvetuotantoalueilla? Suo 52: 2, 75-77.

Pinkerton E 1989. Cooperative management of local fisheries, new directions for improvement, management and community development. UBC Press, Vancouver.

Pretty J 2011. Interdisciplinary progress in approaches to address social-ecological and ecocultural systems. Environmental Conservation 38: 2, 127139 .http://dx.doi.org/10.1017\% 2 FS0376892910000937.

Saloheimo V 2010. Selkien vuodinjako 1774. In Mustonen T (ed). Selkien perinteestä ja luonnosta, 11-16. Selkien kyläyhdistys, Selkie.

Selkien kyläyhdistys 2004. Selkie - kulttuurikylä. Jyväskylä.

Sheridan J \& Longboat RD 2006. The Haudenosaunee imagination and the ecology of the sacred. Space and Culture 9: 4, 365-381. http://dx.doi.org/10.1177\%2F1206331206292503.

Stammler F 2005. Reindeer nomads meet the market: Culture, property and globalisation at the 'End of the Land'. LIT Verlag, Berlin.

Tanskanen M 2000. Näkyvän takana - Tutkimus metsäojitetun suomaiseman kulttuurisuudesta. Joensuun yliopisto, Joensuu.

VAPO 2012. Peat production on sulfide soil. Case Linnunsuo in Eastern Finland. In Geological Survey of Finland. 7th International acid sulfate soil conference. Towards harmony between land use and the environment. Proceedings Volume. Vaasa.

Vesajoki H \& Pihlatie M 2011. Pielisjoki - Elämän virta, Stream of Life. Hyvinkää.

Watson A \& Huntington H 2008. They're here - I can feel them: The epistemic spaces of indigenous and Western knowledges. Social \& Cultural Geography 9: 3, 257-281. http://dx.doi.org/10.1080\% 2F14649360801990488. 